\title{
The Effect of Sandstone Composition on Distribution of Tafoni Landforms in the Aghajari Sandstone, Northwest of Masjed Soleyman, Iran
}

\author{
Amir Ahmadi, ${ }^{1}$ Ebrahim Moghimi, ${ }^{1}$ Seyed Mohamad Zamanzadeh, ${ }^{1}$ and Reza Motamed ${ }^{2}$ \\ ${ }^{1}$ Faculty of Geography, University of Tehran, Tehran 1439951154, Iran \\ ${ }^{2}$ Faculty of Geography, University of Kharazmi, Tehran 3197937551, Iran \\ Correspondence should be addressed to Amir Ahmadi; amirahmadi@ut.ac.ir
}

Received 27 February 2015; Revised 26 April 2015; Accepted 26 May 2015

Academic Editor: Lawrence H. Tanner

Copyright (C) 2015 Amir Ahmadi et al. This is an open access article distributed under the Creative Commons Attribution License, which permits unrestricted use, distribution, and reproduction in any medium, provided the original work is properly cited.

The Aghajari sandstone layers are located in the west of Zagros Mountains from several centimeters thicknesses to maximum 6 meters with carbonating content. Laboratory and fieldwork show high amount of carbonate content through sandstone layers and tafoni and honeycombs (THs) in early layers. In the study area three parameters have the most effective impactful factors in tafoni and honeycombs (THs) including matrix, carbonate content, and porosity. In this study result shows overlays of high ranges of $\mathrm{CaCO}_{3}$, porosity, and low matrix in the early layers (especially in $\mathrm{A}, \mathrm{B}, \mathrm{C}, \mathrm{D}$, and $\mathrm{H}$ layers) with tafoni and honeycombs (THs). Overall, we conclude that matrix and $\mathrm{CaCO}_{3}$ (carbonate clast including carbonate lithics, fragment fossils, and Pellet) and porosity have direct relationships and matrix reverse relationships with tafoni and honeycombs (THs) in the Aghajari sandstones layers.

\section{Introduction}

In sandstone landscapes, tafoni and honeycombs (THs) are the most common small-scale weathering forms on near-vertical bare rock surfaces [1]. Tafoni are the most important geomorphic landforms which were studied in the world [1-7]. It was observed that in the Mediterranean climate tafoni and honeycombs (THs) are more common and better developed in arid and semiarid climate conditions [8-10]. A wide range of conditions may control the formation and development of tafoni and honeycombs (THs) such as mineralogy [9]. Lithological controls have the greatest effect on the mechanical behavior of stones and are themselves controlled by factors such as mineral composition, type and amount of cement, matrix, and porosity of sandstones [3, 11-14]. These controls cause large differences on the earth surface [3]. Dissolution of chemically unstable grains such as feldspars and carbonates results in development of porosity in the rocks [15]. Also chemical processes cause changes in the structure of chemical rocks. For example, calcium carbonate is one of the parameters that are highly affected by chemical reactions [16]. So, if these minerals are present in the rocks, they can cause development of specific landforms (such as tafoni and honeycombs (THs)) which are highly affected by chemical processes $[2,3,9]$. On the other hand, development of porosity in sandstones by dissolution of carbonate cement and calcium carbonate grains causes instability in the rocks and their fragmentation [11, 15, 17], thus reducing strength of the rocks and their breakdown can result in development of tafoni and honeycombs (THs). So, the type of bedrock and its composition control the rock erosion rate fundamentally $[16,18,19]$. Porosity and carbonate framework grains, matrix, and cement are four components of sandstones which greatly affect the morphology of these sandstones [16]. Therefore, the present study is an attempt to illustrate the relationship between the $\mathrm{CaCO}_{3}$ content and role of porosity and matrix in tafoni and honeycombs (THs) development.

\section{Study Area}

The study area is located in the southwest of Iran, northwest of Masjed Soleyman city, situated in the central part of the Jahangiry County near Parneveshteh village. It covers an area 


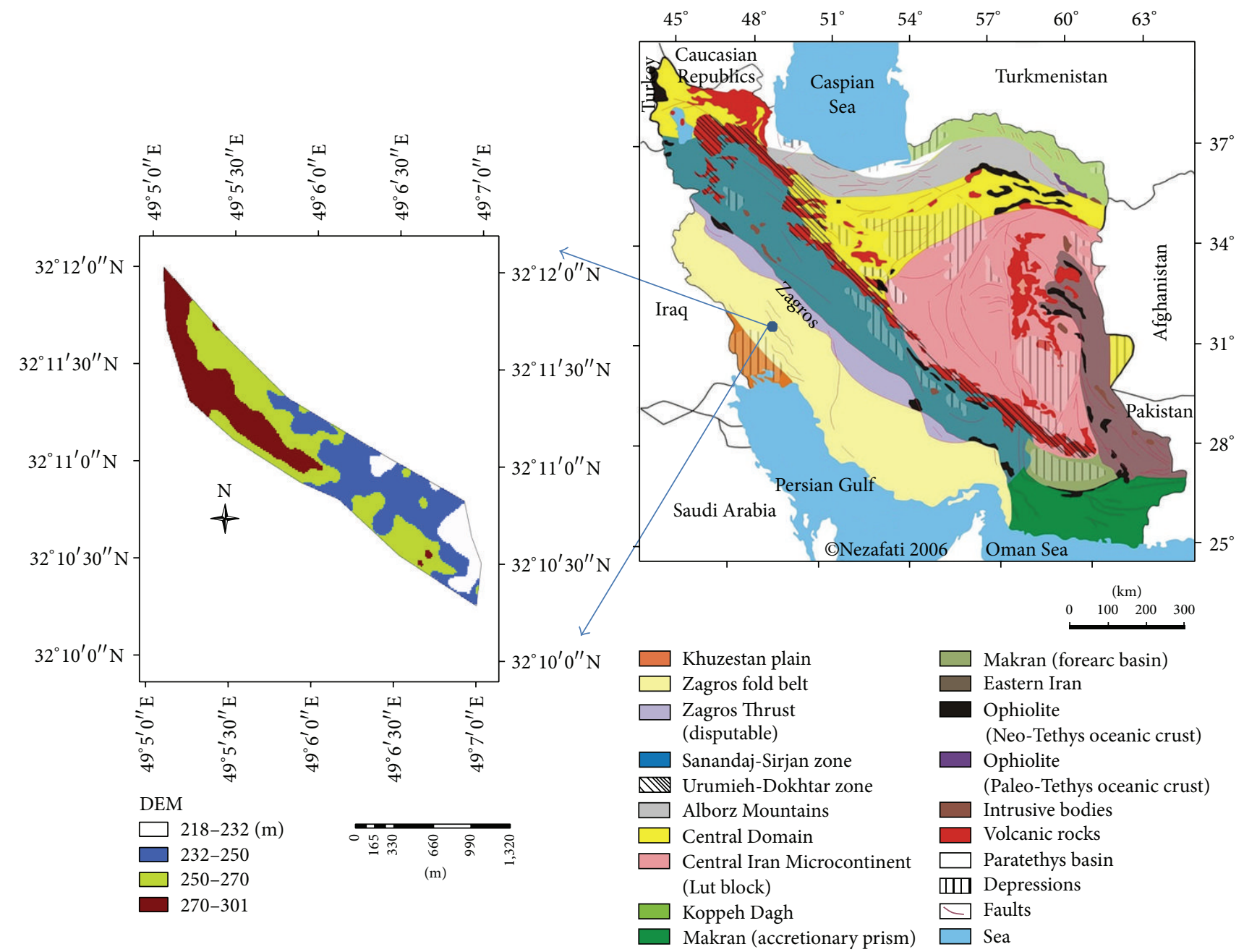

FIGURE 1: The location of study area in the southwest of geological map of Iran.

of $3.2 \mathrm{~km}^{2}$ and is located between $32^{\circ} 10^{\prime} 17^{\prime \prime} \mathrm{N}$ and $32^{\circ} 11^{\prime} 59^{\prime \prime} \mathrm{N}$ and $49^{\circ} 5^{\prime} 5^{\prime \prime} \mathrm{E}$ and $49^{\circ} 7^{\prime} 5^{\prime \prime} \mathrm{E}$. The highest elevation is about $301 \mathrm{~m}$ above sea level in the middle and northwestern part while the minimum elevation is about $218 \mathrm{~m}$ above sea level in the east and northeast (Figure 1). The climate of the study area is Mediterranean $[20,21]$, so the semiarid conditions with cool winters and dry summers prevail. Mean annual precipitation and mean annual temperature in the study area are $523 \mathrm{~mm}$ and $25.5^{\circ} \mathrm{C}$, respectively [22].

\section{Geological Setting}

The Aghajari sandstone layers were produced by erosion of Zagros Mountains and deposited on the rivers and estuary environments [23]. They are a part of the Fars group including Gachsaran (lower Fars), Mishan (middle Fars), and the Aghajari (upper Fars) Formations [24]. The Aghajari sandstone layers are composed of 2 to $5 \mathrm{~km}$ thick gray and greenish sandstones [25]. The study area is located in Dezful embayment. The age of the Aghajari sandstone layers is determined as middle Miocene-upper Pliocene [23, 26] (Figure 2).
3.1. Geomorphology. Diversity of geomorphic landforms in the Aghajari sandstone layers is one of the most interesting properties of the formation. The most important landforms include crests, rivers, cliffs and bulkheads, stone hillsides, fault line (Figure 3), and various tafoni and honeycombs (THs) including basal tafoni, side tafoni, horn tafoni, and pseudotafoni (Figure 4). Distribution of landforms indicates that stone hillsides and cliffs and bulkheads have NW-SE orientation throughout the study area. This is the general trend of Zagros Mountains that resulted from continental collision between Arabian and Iranian plates in the late Mesozoic $[23,27-32]$. The area represented by tafoni and honeycombs (THs) is located in the southern half of the study area.

\section{Materials}

In this study, we took samples along eight layers which are named A to H. Samples A1 to A6 were taken from the oldest layer and samples $\mathrm{H} 1$ to $\mathrm{H} 6$ belonged to the youngest one (Figure 5). Because the thickness of layers varied from place to place, the sampling interval changes from 50 to 150 meters. Landforms geomorphic map of the study area was prepared 


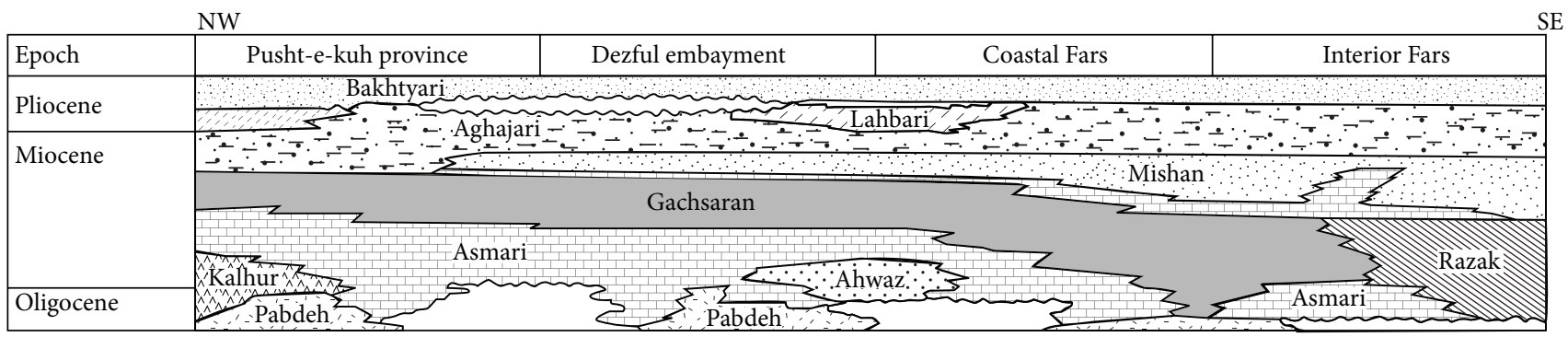

Conglomerate

Anhydrite

Shale, marl, and sandstone

Erosion

Shale, marl

Figure 2: Stratigraphic situation of the Aghajari sandstone Formation in Zagros Cenozoic stratigraphy [36].

TABLE 1: Mean values of calcium carbonate percentage $\left(\mathrm{CaCO}_{3}\right)$ in 8 layers $(\mathrm{A}, \mathrm{B}, \mathrm{C}, \ldots$, and $\mathrm{H})$ in the study area.

\begin{tabular}{|c|c|c|c|c|c|c|c|c|}
\hline \multirow[b]{2}{*}{ Number } & \multicolumn{8}{|c|}{ Sample } \\
\hline & $\begin{array}{c}\mathrm{A} \\
\mathrm{CaCO}_{3}(\%)\end{array}$ & $\begin{array}{c}\mathrm{B} \\
(\%)\end{array}$ & $\begin{array}{c}\mathrm{C} \\
(\%)\end{array}$ & $\begin{array}{l}\mathrm{D} \\
(\%)\end{array}$ & $\begin{array}{c}\mathrm{E} \\
(\%)\end{array}$ & $\begin{array}{c}\mathrm{F} \\
(\%)\end{array}$ & $\begin{array}{c}\mathrm{G} \\
(\%)\end{array}$ & $\begin{array}{l}\mathrm{H} \\
(\%)\end{array}$ \\
\hline 1 & 45.33 & 41.33 & 52 & 66.66 & 49.33 & 50.66 & 42.35 & 30.66 \\
\hline 2 & 45.33 & 34.66 & 46.66 & 42.66 & 42.66 & 60 & 56 & 56 \\
\hline 3 & 30.66 & 61.33 & 50.66 & 42.66 & 56 & 42.66 & 40 & 53.33 \\
\hline 4 & 50.66 & 42.66 & 68 & 50.66 & 24 & 56 & 68 & 62.66 \\
\hline 5 & 40 & 41.33 & 42.66 & 44 & 53.33 & 53.33 & 57.33 & 40 \\
\hline 6 & 44 & 38.66 & 45.33 & 42.66 & 49.33 & 62.35 & 65.33 & 50.66 \\
\hline
\end{tabular}

TABLE 2: Mean values of porosity percentage in 8 layers $(A, B, C, \ldots$, and $H)$ in the study area.

\begin{tabular}{|c|c|c|c|c|c|c|c|c|}
\hline \multirow[b]{2}{*}{ Number } & \multicolumn{8}{|c|}{ Sample } \\
\hline & $\begin{array}{c}\text { A } \\
\text { Porosity (\%) }\end{array}$ & $\begin{array}{c}\mathrm{B} \\
(\%)\end{array}$ & $\begin{array}{c}\mathrm{C} \\
(\%)\end{array}$ & $\begin{array}{c}\mathrm{D} \\
(\%)\end{array}$ & $\begin{array}{c}\mathrm{E} \\
(\%) \\
\end{array}$ & $\begin{array}{c}\mathrm{F} \\
(\%) \\
\end{array}$ & $\begin{array}{c}\text { G } \\
(\%) \\
\end{array}$ & $\begin{array}{c}\mathrm{H} \\
(\%)\end{array}$ \\
\hline 1 & 84 & 51 & 87 & 7 & 4 & 1 & 3 & 17 \\
\hline 2 & 38 & 21 & 26 & 18 & 22 & 37 & 0 & 2 \\
\hline 3 & 51 & 7 & 4 & 12 & 5 & 11 & 9 & 1 \\
\hline 4 & 50 & 33 & 8 & 1 & 7 & 0 & 33 & 28 \\
\hline 5 & 8 & 2 & 1 & 26 & 1 & 1 & 10 & 35 \\
\hline 6 & 39 & 18 & 31 & 16 & 1 & 9 & 15 & 5 \\
\hline
\end{tabular}

by FreeHand software via using 1:25,000 topographic maps of Iranian National Survey Organization. Geological data, such as lithology and contacts of the Aghajari sandstone layers, were derived from 1:100,000 geological maps of Geological Survey of Iran. ArcGIS and Excel software were used to draw zoning map of $\mathrm{CaCO}_{3}$ and porosity distribution and scatter plot, respectively; then zoning maps and geomorphic map of the landforms were overlaid by FreeHand.

4.1. Laboratory Methods. Bernard calcimeter was used to determine calcium carbonate percentage in each sample. First $0.1 \mathrm{~g}$ powder of each sandstone sample was prepared. Then $15 \mathrm{cc}$ of normal hydrochloric acid was added to $0.1 \mathrm{~g}$ powdered sandstone and the container was gently shaken for 25 minutes.
In this reaction the amount of $\mathrm{CO}_{2}$ of each sample was precisely (up to $\pm 1 \mathrm{cc}$ ) recorded. Then $0.1 \mathrm{~g}$ of pure calcium carbonate sample (Merck) was used in the same reaction system under the same conditions and then results of $\mathrm{CO}_{2}$ content were recorded as well.

The content of calcium carbonate in each sample was calculated according to the following formula:

$\mathrm{CaCO}_{3}$ percent $=100 *$ Calcium carbonate of the samples/pure calcium carbonate (Table 1).

4.1.1. Thin Section Study. Thin section samples were prepared from fresh rock samples. After preparing thin sections, porosity (Table 2), matrix percent (Table 3 ), and carbonate clast (Table 4) were determined via point counting by counting 400 points in each sample by using JMicroVision software. 


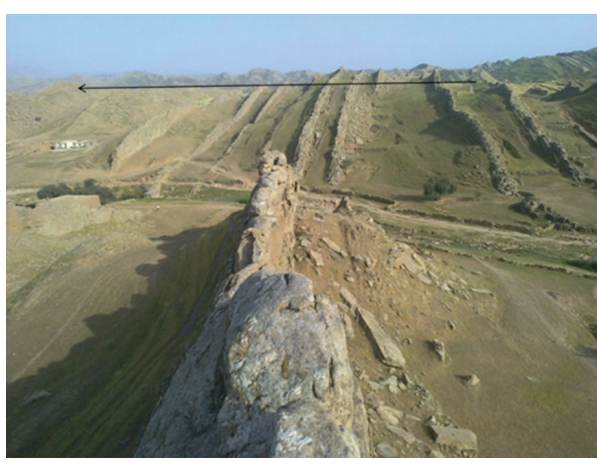

(a)

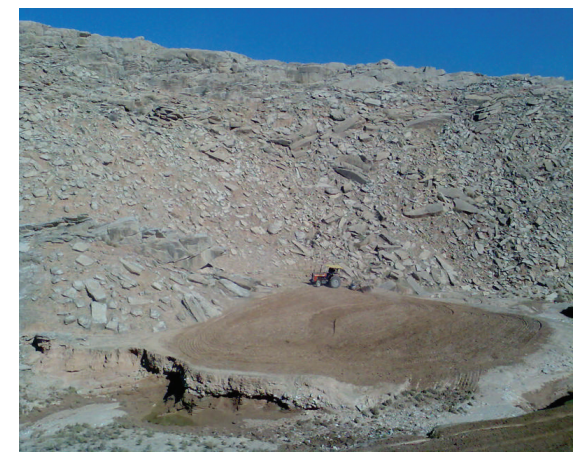

(c)

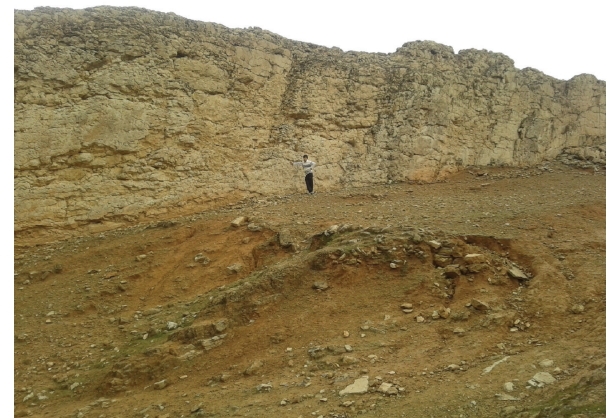

(b)

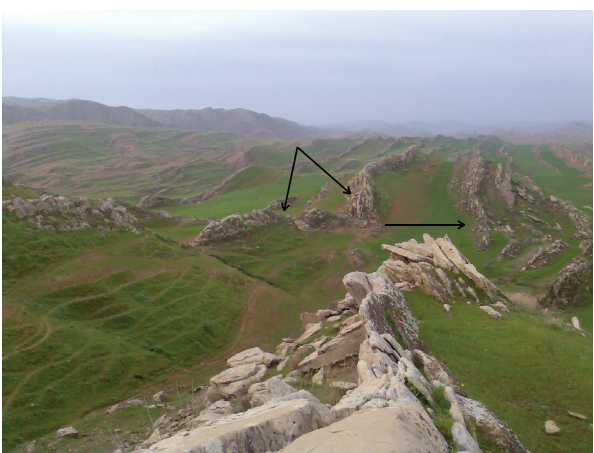

(d)
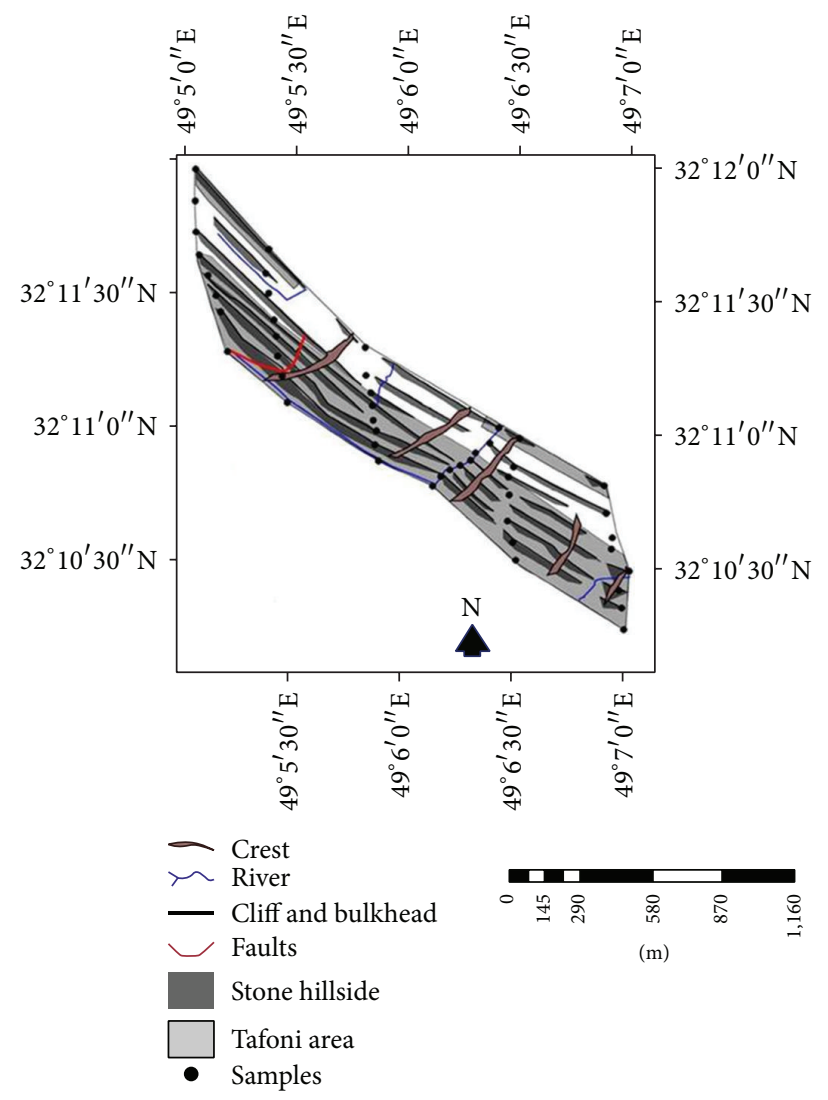

$(\mathrm{m})$

(e)

FIGURE 3: Geomorphic landforms in the study area. (a) Crest (more than $2 \mathrm{~km}$ ) created by passing rivers from sandstone layers, (b) cliff and bulkhead (almost 10 meters) in F layer because of high matrix (77.8\%) and low porosity (10\%), (c) stone hillside (almost 20 meters) because of high porosity (22\%) and low matrix (52\%), (d) faults line in the layers width, and (e) geomorphic landforms map in the study area including crests rivers, cliff and bulkheads, faults, stone hillsides, and tafoni and honeycombs (THs) which covered about $65 \%$ of study area. 


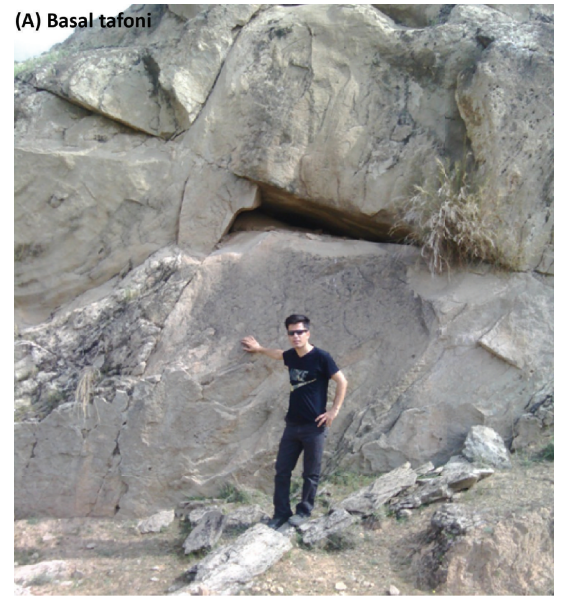

(a)

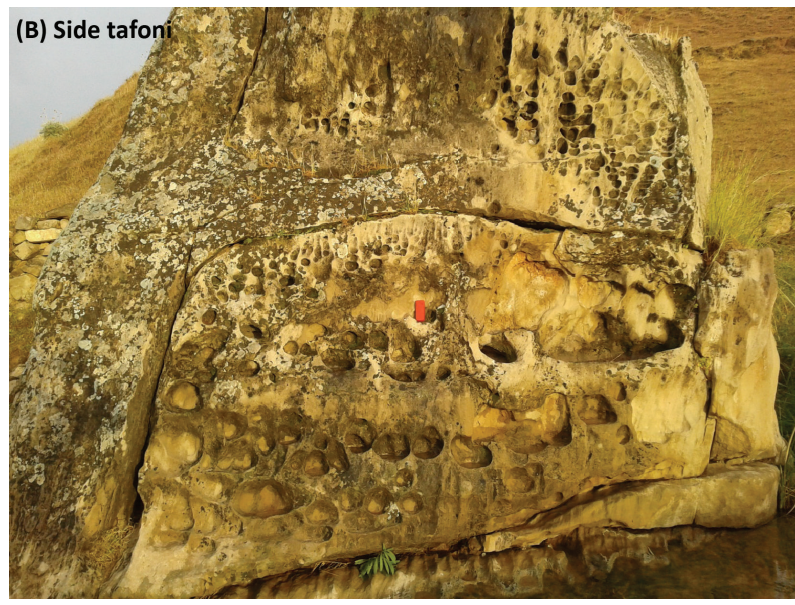

(b)

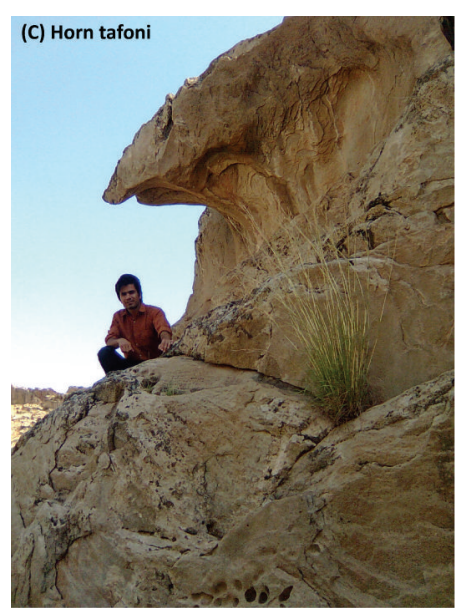

(c)

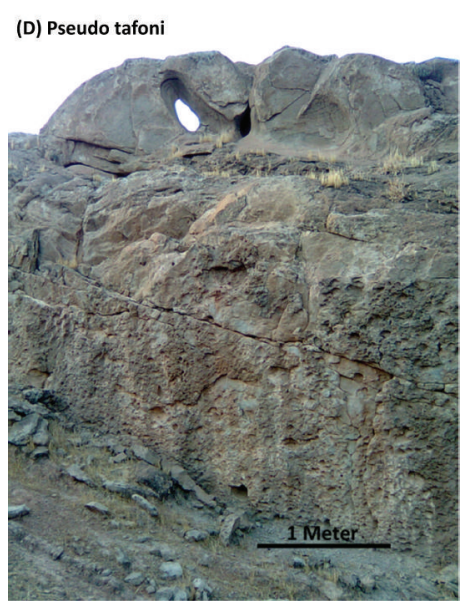

(d)

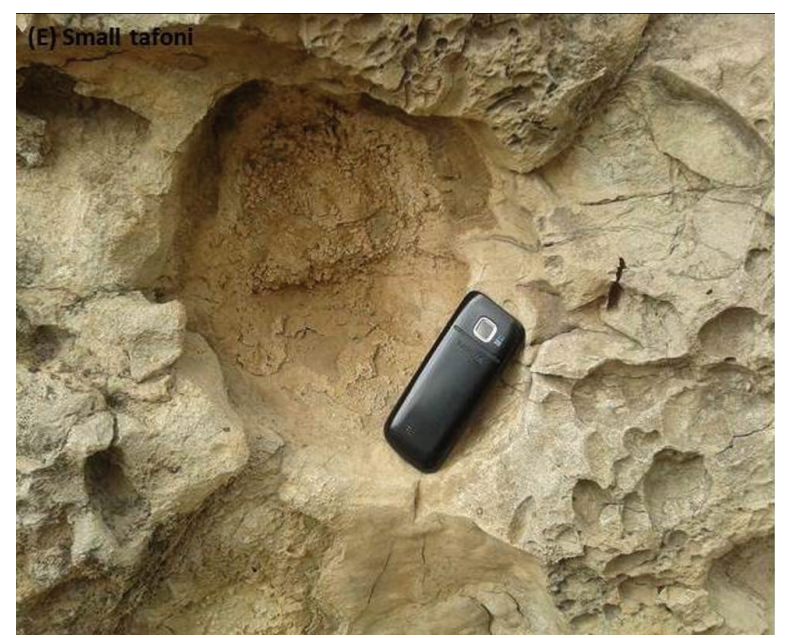

(e)

Figure 4: Different types of tafoni and honeycombs (THs) in the study area. (a) Basal tafoni (this kind of tafoni was created along fractures and represented selective weathering along the fractures and reduced rock masses strength) [37], (b) side tafoni and honeycombs (narrow indicated cellphone (about $10 \mathrm{~cm}$ ) is a scale). (c) Horn tafoni, (d) pseudotafoni. (e) Small tafoni accompanied by carbonate cortex in cavity.

TABLE 3: Mean values of matrix percentage in 8 layers $(A, B, C, \ldots$, and $H)$ in the study area.

\begin{tabular}{|c|c|c|c|c|c|c|c|c|}
\hline \multirow[b]{2}{*}{ Number } & \multicolumn{8}{|c|}{ Sample } \\
\hline & $\begin{array}{c}\text { A } \\
\text { Matrix (\%) }\end{array}$ & $\begin{array}{c}\mathrm{B} \\
(\%) \\
\end{array}$ & $\begin{array}{c}\mathrm{C} \\
(\%) \\
\end{array}$ & $\begin{array}{c}\mathrm{D} \\
(\%) \\
\end{array}$ & $\begin{array}{c}\mathrm{E} \\
(\%)\end{array}$ & $\begin{array}{c}\mathrm{F} \\
(\%)\end{array}$ & $\begin{array}{c}\text { G } \\
(\%)\end{array}$ & $\begin{array}{c}\mathrm{H} \\
(\%) \\
\end{array}$ \\
\hline 1 & 11 & 40 & 6 & 77 & 87 & 80 & 57 & 73 \\
\hline 2 & 32 & 49 & 35 & 31 & 66 & 62 & 89 & 96 \\
\hline 3 & 48 & 53 & 68 & 53 & 54 & 84 & 46 & 77 \\
\hline 4 & 45 & 60 & 85 & 63 & 88 & 85 & 74 & 70 \\
\hline 5 & 80 & 68 & 91 & 50 & 87 & 69 & 87 & 59 \\
\hline 6 & 27 & 44 & 43 & 54 & 68 & 87 & 73 & 68 \\
\hline
\end{tabular}

TABLE 4: Mean values of carbonate content percentage in 8 layers $(A, B, C, \ldots$, and $H)$ in the study area.

\begin{tabular}{lcccccccc}
\hline Layers & A & B & C & D & E & F & G & H \\
\hline Mean carbonate clasts (\%) & 33.66 & 32.33 & 30 & 17.33 & 22.33 & 28.84 & 27.5 & 32.66 \\
\hline
\end{tabular}




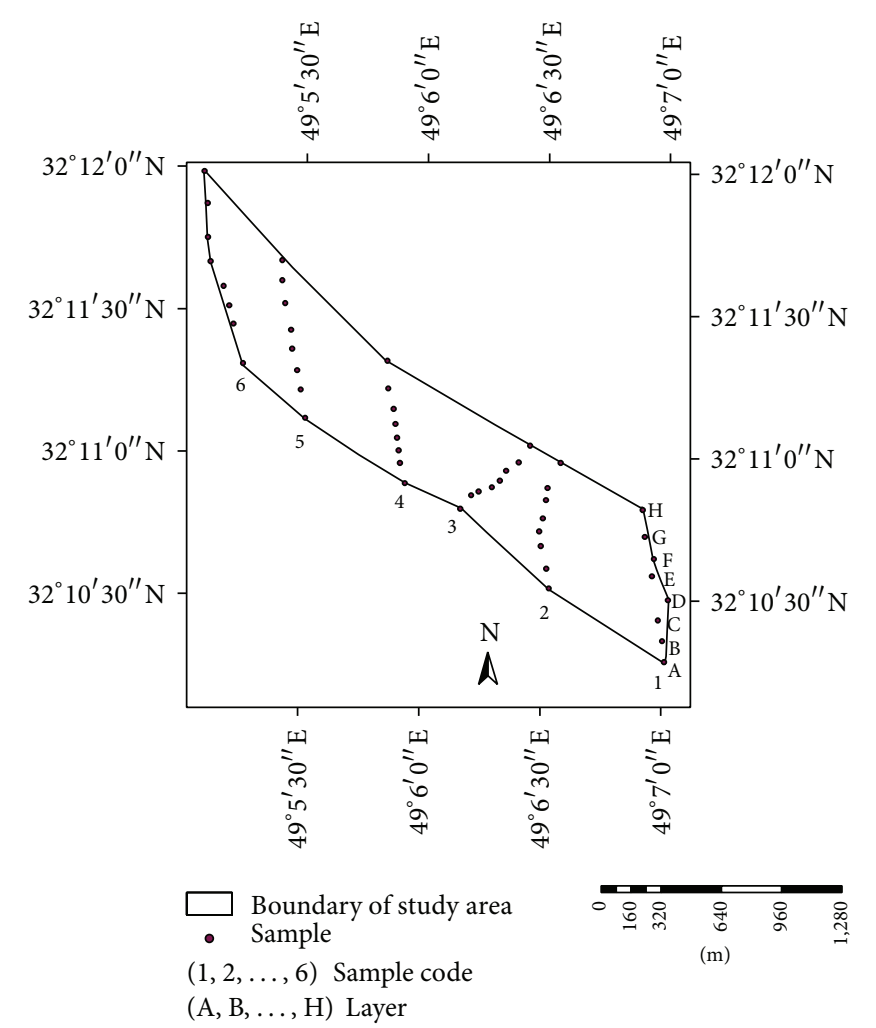

Figure 5: Layers (A, B, C, ... and $\mathrm{H}$ ) and sampling grids in the study area.

\section{Results}

Composition of lithology in the study area includes quartz (34.45\%), peloids (29.91\%), lithics (mostly carbonate) (16.31\%), feldspar (11.98\%), and iron oxide (7.23\%), and the dominant cements are calcite and dolomite (Figures 6(a), 6(b), and 6(c)). Mean calcium carbonate percentage, matrix, porosity, and carbonate clast in the study area are, respectively, as follows: $48.58 \%, 62.43 \%, 18.57 \%$, and $28 \%$. Calcium carbonate zoning map showed five zones with different ranges between a minimum of $26 \%$ and a maximum of $68 \%$ (Figure 8 ). The section with a range of $46-56 \%$ occupies more than $60 \%$ of total study area. The section with a range of 26-36\% comprises the smallest area which is shown by some dots in the map (Figure 8). The effect of $\mathrm{CaCO}_{3}$ content on tafoni and honeycombs (THs) can be discussed as follows: usually most of tafoni and honeycombs (THs) features are observed in the layers with $36-56 \%$ of carbonate content in the region. In this zone, the diversity and frequency of tafoni and honeycombs (THs) depend on amount of $\mathrm{CaCO}_{3}$ content, porosity, and matrix. Also there is a direct relationship between the number and diversity of tafoni and honeycombs (THs) with carbonate clast and porosity, strong inversely relationship to matrix (Figures 8,9 , and 10).

\section{Discussion}

Calcareous sandstones contain a significant quantity (10$50 \%$ ) of carbonate grains, skeletal fragments, peloids, and ooids, with more than $50 \%$ carbonate grains [33]. Carbonate cements in sandstones consist of calcite, dolomite, and occasionally siderite [16]. Peloids (29.91\%), calcite cement (19\%), dolomite cement, fossils and skeletal fragments, and carbonate lithics in the study area (Figures 6(a), 6(b), and 6(c)) are highly affected by dissolution processes [34] (Figure 6(b)). And they almost represent the total $\mathrm{CaCO}_{3}$ [33]. Dissolution of chemically unstable grains such as carbonates creates porosity in these rocks [15] (Figures 4(e) and 6(b)). Dissolution often is controlled by soluble minerals, for example, calcium carbonate [35]. The mean content of $\mathrm{CaCO}_{3}$ $(48.58 \%)$ indicates a relatively high amount of $\mathrm{CaCO}_{3}$ in the Aghajari sandstone layers. Moreover, mean variation of $\mathrm{CaCO}_{3}$, matrix, and porosity are $12.17 \%, 37.33 \%$, and $38.4 \%$, respectively (Tables 1, 2, and 3). This comparison showed that the mean variation of $\mathrm{CaCO}_{3}$ is less than matrix and porosity. By descending porosity and carbonate content and ascending matrix, the number and diversity of tafoni and honeycombs are reduced. Eventually matrix and carbonate content have controlling roles in amount of porosity that affected the tafoni and honeycombs (THs) through sandstone layers.

6.1. The Effect of $\mathrm{CaCO}_{3}$ Content, Porosity, and Matrix on Tafoni. Generally speaking, tafoni and honeycombs (THs) are observed in five layers (A, B, C, D, and H) (Figures 8, 9 , and 10). Fieldwork and survey in the study area represent the fact that diversity and number of tafoni and honeycombs (THs) are high (Figures 4(a), 4(b), 4(c), 4(d), and 4(e) and 8,9 , and 10 ), and they covered about $65 \%$ of study area (a little more than $2 \mathrm{~km}^{2}$ ) (Figure 3). As seen in Figures 7(a) and 7(b), using trends, we found a negative association 


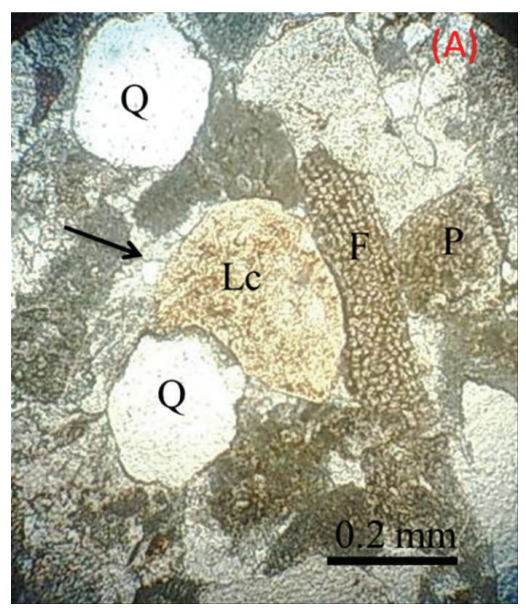

(a)

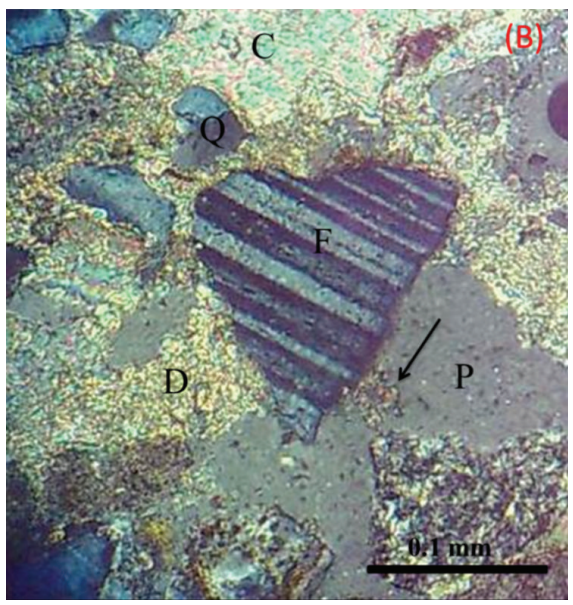

(b)

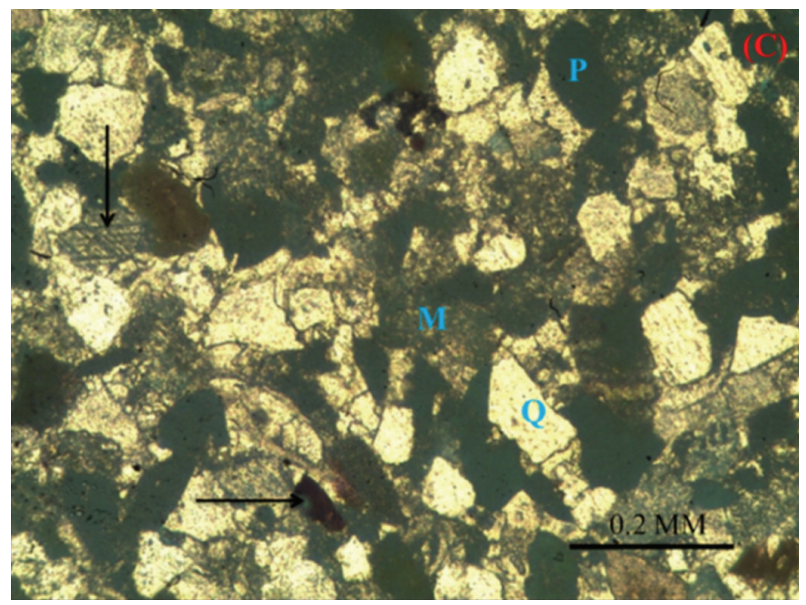

(c)

Figure 6: Microscopic images of Aghajari sandstone under polarized light. (a) Illustrating quartz (Q), carbonate lithic (Lc) fossil fragments $(\mathrm{F})$, peloid (P), and calcite cement shown by arrow. (b) Abundant calcite (C) and dolomite (D) cements with floating grains of feldspar (F) and quartz in them; arrows show remaining particles of cement in porosity $(\mathrm{P})$. (c) Development of carbonate matrix $(\mathrm{M})$ among the particles especially peloid (P), iron oxide (horizontal arrow), and calcite (vertical arrow).

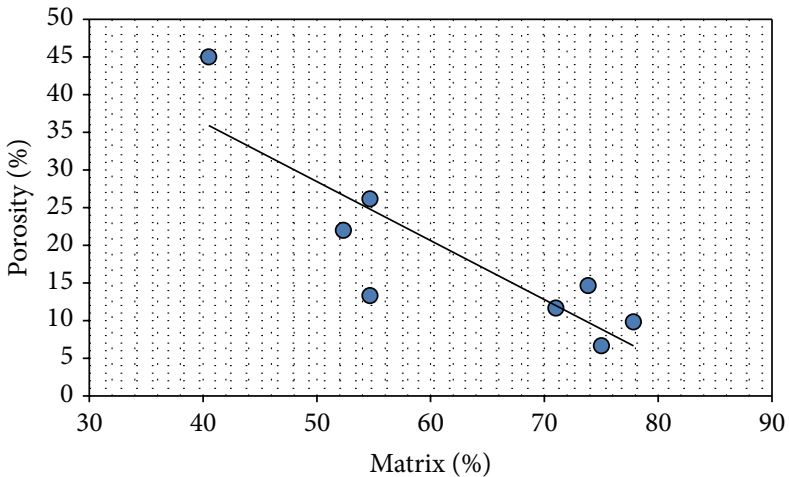

(a)

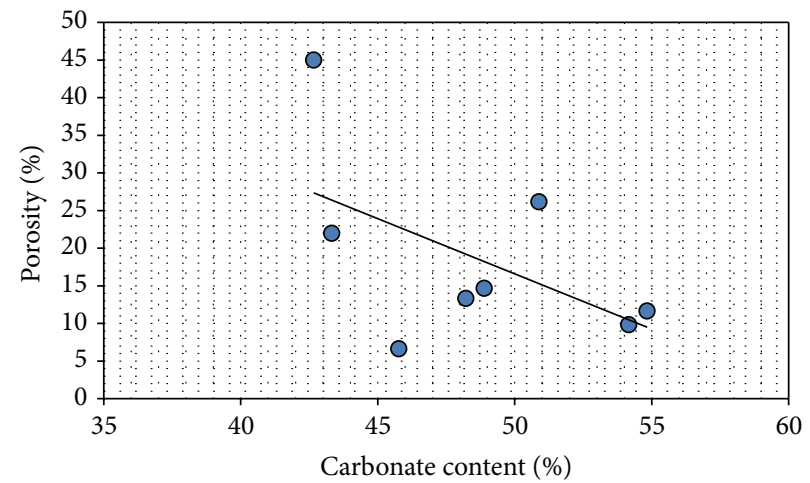

(b)

FIgURE 7: Scatter plot (a) matrix and porosity, (b) carbonate content and porosity. 


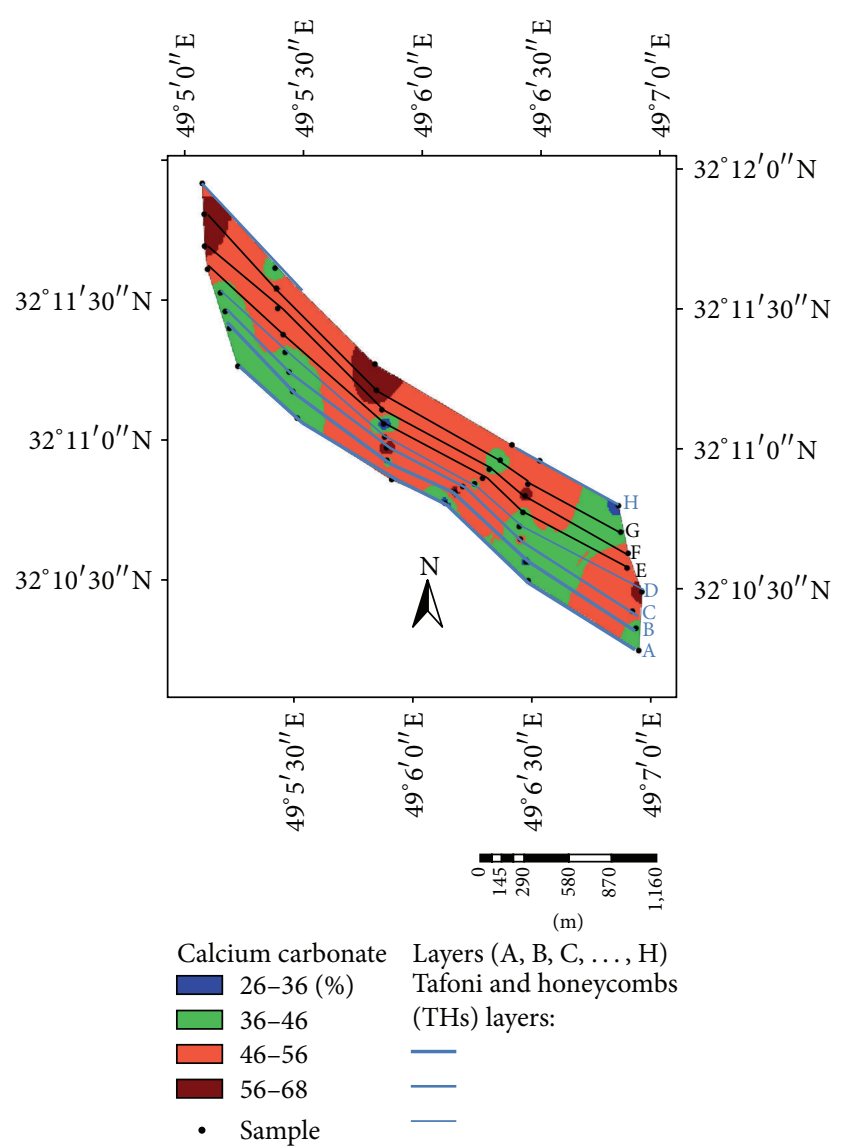

FIgURE 8: Overlay of tafoni and honeycombs (THs) with zoning maps of calcium carbonate $\left(\mathrm{CaCO}_{3}\right)$. In this picture, $\mathrm{A}, \mathrm{B}, \mathrm{C}, \mathrm{D}$, and $\mathrm{H}$ layers (blue colored layers) possess tafoni and honeycombs (THs). The number and diversity of tafoni and honeycombs (THs) reduce from A to D layers. The thick line in A layer and slender line in D layer are representative of the highest and the lowest number and diversity of tafoni and honeycombs (THs), respectively.

between either carbonate content and porosity or matrix and porosity. In this regard, we can see that amount of matrix and carbonate content has a controlling role over the amount of porosity. This decreasing trend of porosity leads to decreasing the numbers and diversity of tafoni and honeycombs (THs) in youngest layer. Reversely, in the older layers tafoni and honeycombs (THs) are more observed (Figures 8, 9, and 10).

Moreover, porosity zoning, $\mathrm{CaCO}_{3}$, and matrix maps show the amounts of $6.6-60 \%, 26-56 \%$, and $6-80 \%$, respectively (Figures 8 and 10). It is worthy of note that domination of tafoni and honeycombs (THs) is overlays with low ranges of matrix and porosity maps in the region (Figures 9 and 10).

\section{Conclusion}

In the Aghajari sandstone layers, mean calcium carbonate percentage, matrix, porosity, and carbonate clast in the study area are, respectively, as follows: $48.58 \%, 62.43 \%, 18.57 \%$, and $28 \%$. Zoning maps show that occurrence of tafoni and

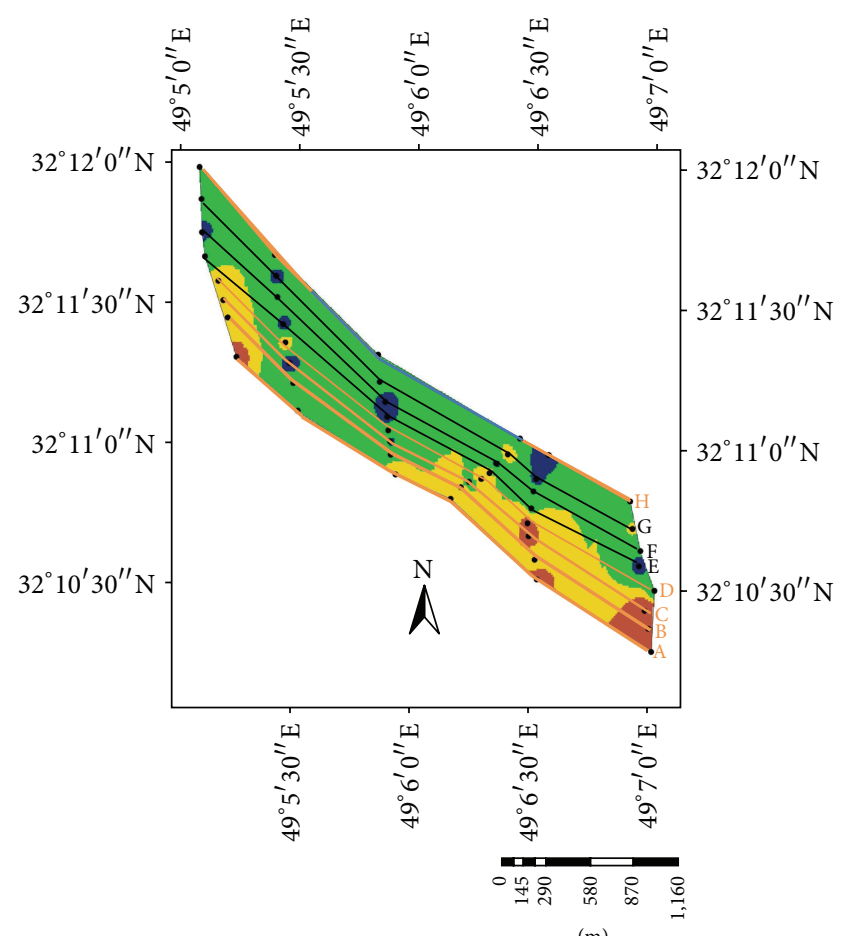

(m)

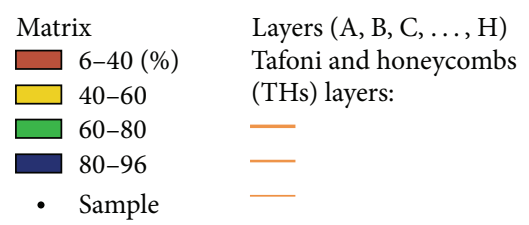

Figure 9: Overlay of tafoni and honeycombs (THs) with zoning maps of matrix. In this figure, $\mathrm{A}, \mathrm{B}, \mathrm{C}, \mathrm{D}$, and $\mathrm{H}$ layers (yellow colored layers) possess tafoni and honeycombs (THs). The number and diversity of tafoni and honeycombs (THs) are reduced from A to $\mathrm{D}$ layers. The thick line in $\mathrm{A}$ layer and slender line in $\mathrm{D}$ layer are representative of the highest and the lowest number and diversity of tafoni and honeycombs (THs), respectively.

honeycombs (THs) and their diversity are concentrated in the layers in which porosity zoning, $\mathrm{CaCO}_{3}$, and matrix maps represent amounts of about $6.6-60 \%, 26-56 \%$, and $6-80 \%$, respectively. Result shows tafoni and honeycombs (THs) are overlays of high ranges of carbonate content, porosity, and low matrix in the early layers (especially in A, B, C, D, and $\mathrm{H}$ layers). Almost, matrix, porosity and $\mathrm{CaCo}_{3}$ (carbonate clast) controlling diversity of tafoni and honeycombs (THs). Overall, there are direct relationships between $\mathrm{CaCO}_{3}$ (carbonate clast including carbonate lithics, fragment fossils, and Pellet) and porosity and reverse relationship matrix with tafoni and honeycombs (THs) in the Aghajari sandstones.

\section{Conflict of Interests}

The authors declare that there is no conflict of interests regarding the publication of this paper. 


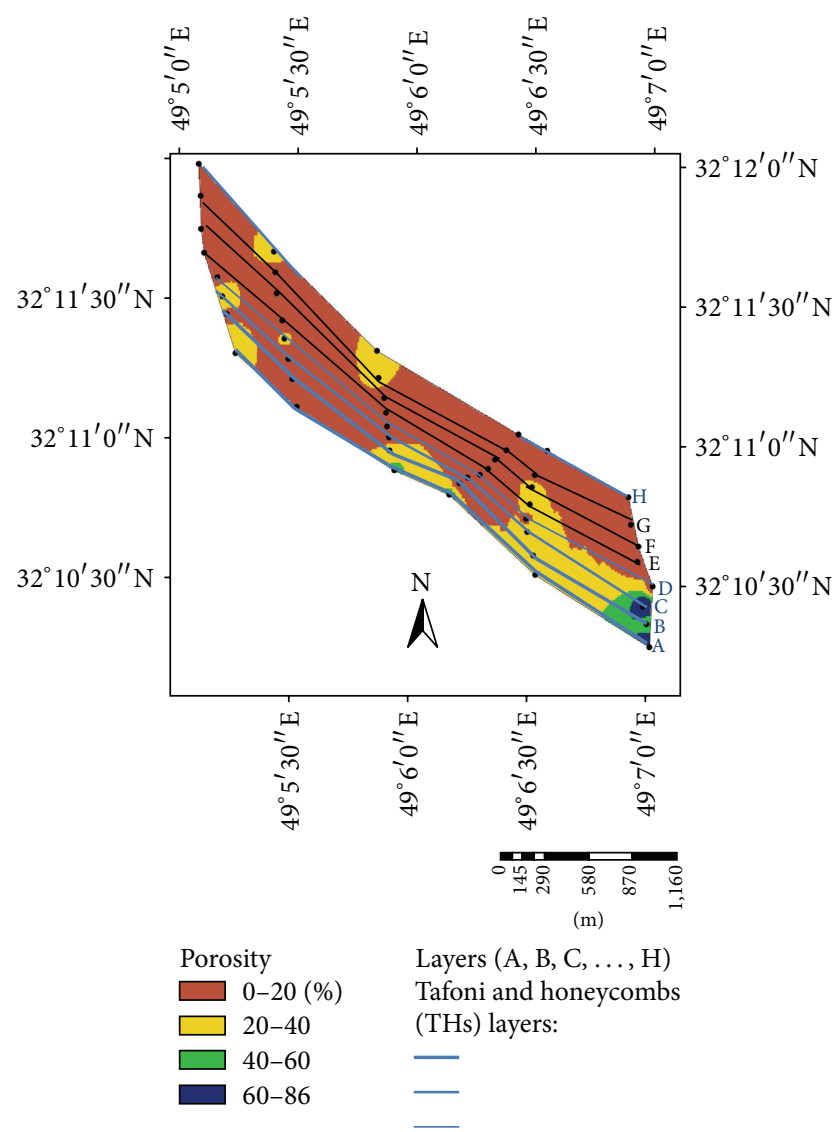

FIGURE 10: Overlay of tafoni and honeycombs (THs) with zoning maps of porosity. In this figure, $\mathrm{A}, \mathrm{B}, \mathrm{C}, \mathrm{D}$, and $\mathrm{H}$ layers (blue colored layers) have tafoni and honeycombs (THs). The number and diversity of tafoni and honeycombs (THs) are reduced from A to $\mathrm{D}$ layers. The thick line in A layer and slender line in D layer are representative of the highest and the lowest number and diversity of tafoni and honeycombs (THs), respectively.

\section{Acknowledgments}

The authors thank the editor Lawrence H. Tanner and anonymous reviewer for improving scientific content of the paper; also thanks are due to Sham Mirzaei for editing English writing.

\section{References}

[1] A. V. Turkington and T. R. Paradise, "Sandstone weathering: a century of research and innovation," Geomorphology, vol. 67, no. 1-2, pp. 229-253, 2005.

[2] D. Kelletat, "Studies on the age of honeycombs and tafoni features," Catena, vol. 7, no. 4, pp. 317-325, 1980.

[3] R. W. Young and R. A. M. Wray, Sandstone Landforms, Cambridge University Press, Cambridge, UK, 2009.

[4] M. André and K. Hall, "Honeycomb development on Alexander Island, glacial history of George VI Sound and palaeoclimatic implications (Two Step Cliffs/Mars Oasis, W Antarctica)," Geomorphology, vol. 65, no. 1-2, pp. 117-138, 2005.
[5] A. Mellor, J. Short, and S. J. Kirkby, "Tafoni in the El Chorro area, Andalucia, southern Spain," Earth Surface Processes and Landforms, vol. 22, no. 9, pp. 817-833, 1997.

[6] Y. Matsukura and Y. Tanaka, "Effect of rock hardness and moisture content on tafoni weathering in the granite of Mount DoegSung, Korea," Geografiska Annaler, Series A: Physical Geography, vol. 82, no. 1, pp. 59-67, 2000.

[7] S. A. Norwick and L. R. Dexter, "Rates of development of Tafoni in the moenkopi and kaibab formations in meteor crater and on the Colorado plateau, Northeastern Arizona," Earth Surface Processes and Landforms, vol. 27, no. 1, pp. 11-26, 2002.

[8] C. Roqué, M. Zarroca, and R. Linares, "Subsurface initiation of tafoni in granite terrains-geophysical evidence from NE Spain: geomorphological implications," Geomorphology, vol. 196, pp. 94-105, 2013.

[9] E. Hejl, "A pictorial study of tafoni development from the 2nd millennium BC," Geomorphology, vol. 64, no. 1-2, pp. 87-95, 2005.

[10] H. G. Dill, B. Weber, and A. Gerdes, "Constraining the physicalchemical conditions of Pleistocene cavernous weathering in Late Paleozoic granites," Geomorphology, vol. 121, no. 3-4, pp. 283-290, 2010.

[11] A. V. Turkington, J. D. Phillips, and S. W. Campbell, "Weathering and landscape evolution," Geomorphology, vol. 67, no. 1-2, pp. 1-6, 2005.

[12] Y.-M. Hsieh, H.-H. Li, T.-H. Huang, and F.-S. Jeng, "Interpretations on how the macroscopic mechanical behavior of sandstone affected by microscopic properties-revealed by bondedparticle model," Engineering Geology, vol. 99, no. 1-2, pp. 1-10, 2008.

[13] M. E. Arribas, J. P. Rodríguez-López, N. Meléndez, A. R. Soria, and P. L. de Boer, "Giant calcite concretions in aeolian dune sandstones; sedimentological and architectural controls on diagenetic heterogeneity, mid-Cretaceous Iberian Desert System, Spain," Sedimentary Geology, vol. 243-244, pp. 130-147, 2012.

[14] J. Nespereira, J. A. Blanco, M. Yenes, and D. Pereira, "Irregular silica cementation in sandstones and its implication on the usability as building stone," Engineering Geology, vol. 115, no. 34, pp. 167-174, 2010.

[15] J. Bridge and R. Demicco, Earth Surface Processes, Landforms and Sediment Deposits, Cambridge University Press, Cambridge, UK, 2008.

[16] R. C. Selley, Applied Sedimentology, Harcourt/Academic Press, New York, NY, USA, 2000.

[17] A. Khidir and O. Catuneanu, "Reservoir characterization of Scollard-age fluvial sandstones, Alberta foredeep," Marine and Petroleum Geology, vol. 27, no. 9, pp. 2037-2050, 2010.

[18] G. Nichols, Sedimentology and Stratigraphy, Wiley-Blackwell, Oxford, UK, 2009.

[19] H. Siedel, S. Pfefferkorn, E. von Plehwe-Leisen, and H. Leisen, "Sandstone weathering in tropical climate: results of lowdestructive investigations at the temple of Angkor Wat, Cambodia," Engineering Geology, vol. 115, no. 3-4, pp. 182-192, 2010.

[20] M. Djamali, S. Brewer, S. W. Breckle, and S. T. Jackson, "Climatic determinism in phytogeographic regionalization: a test from the Irano-Turanian region, SW and Central Asia," Flora, vol. 207, no. 4, pp. 237-249, 2012.

[21] L. R. Stevens, E. Ito, A. Schwalb, and H. E. Wright Jr., “Timing of atmospheric precipitation in the Zagros Mountains inferred from a multi-proxy record from Lake Mirabad, Iran," Quaternary Research, vol. 66, no. 3, pp. 494-500, 2006. 
[22] A. Ahmadi, Quaternary morphogenesis of mechanism on Aghajari sandstone in Northwest Masjed-soleyman [M.S. thesis], Faculty of Geography, University of Tehran, Tehran, Iran, 2013.

[23] H. Motiei, Stratigraphy of Zagros, Geological Survey of Iran, 1993, (Persian).

[24] A. Bahroudi and H. A. Koyi, “Tectono-sedimentary framework of the Gachsaran Formation in the Zagros foreland basin," Marine and Petroleum Geology, vol. 21, no. 10, pp. 1295-1310, 2004.

[25] R. Nateghi, "Prediction of ground vibration level induced by blasting at different rock units," International Journal of Rock Mechanics \& Mining Sciences, vol. 48, no. 6, pp. 899-908, 2011.

[26] S. Homke, J. Vergés, M. Garcés, H. Emami, and R. Karpuz, "Magnetostratigraphy of Miocene-Pliocene Zagros foreland deposits in the front of the Push-e Kush Arc (Lurestan Province, Iran)," Earth and Planetary Science Letters, vol. 225, no. 3-4, pp. 397-410, 2004.

[27] S. Sherkati and J. Letouzey, "Variation of structural style and basin evolution in the central Zagros (Izeh zone and Dezful Embayment), Iran," Marine and Petroleum Geology, vol. 21, no. 5, pp. 535-554, 2004.

[28] M. Berberian, "Master 'blind' thrust faults hidden under the Zagros folds: active basement tectonics and surface morphotectonics," Tectonophysics, vol. 241, no. 3-4, pp. 193-224, 1995.

[29] K. Mobasher and H. A. Babaie, "Kinematic significance of foldand fault-related fracture systems in the Zagros mountains, southern Iran," Tectonophysics, vol. 451, no. 1-4, pp. 156-169, 2008.

[30] P. Navabpour and E. Barrier, "Stress states in the Zagros foldand-thrust belt from passive margin to collisional tectonic setting," Tectonophysics, vol. 581, pp. 76-83, 2012.

[31] J. Stocklin, "Structural history and tectonics of Iran: a review," The American Association of Petroleum Geologists Bulletin, vol. 52, no. 7, pp. 1229-1258, 1968.

[32] M. Alavi, "Tectonics of the zagros orogenic belt of iran: new data and interpretations," Tectonophysics, vol. 229, no. 3-4, pp. 211$238,1994$.

[33] M. E. Tucker, The Field Description of Sedimentary Rocks, The Open University Press Comprises, Milton Keynes, UK, 1982.

[34] K. W. Glennie, Development in Sedimentary: Desert Sedimentary Environments, Elsevier, Amsterdam, The Netherlands, 1970.

[35] R. Aubrecht, T. Lánczos, M. Gregor et al., "Sandstone caves on Venezuelan tepuis: return to pseudokarst?" Geomorphology, vol. 132, no. 3-4, pp. 351-365, 2011.

[36] G. A. James and J. G. Wynd, "Stratigraphical nomenclature of Iranian oil consortium agreement area," American Association of Petroleum Geologists Bulletin, no. 49, pp. 2182-2245, 1965.

[37] A. S. Goudie, Encyclopedia of Geomorphology, vol. 1 A-I, Routledge, London, UK, 2004. 

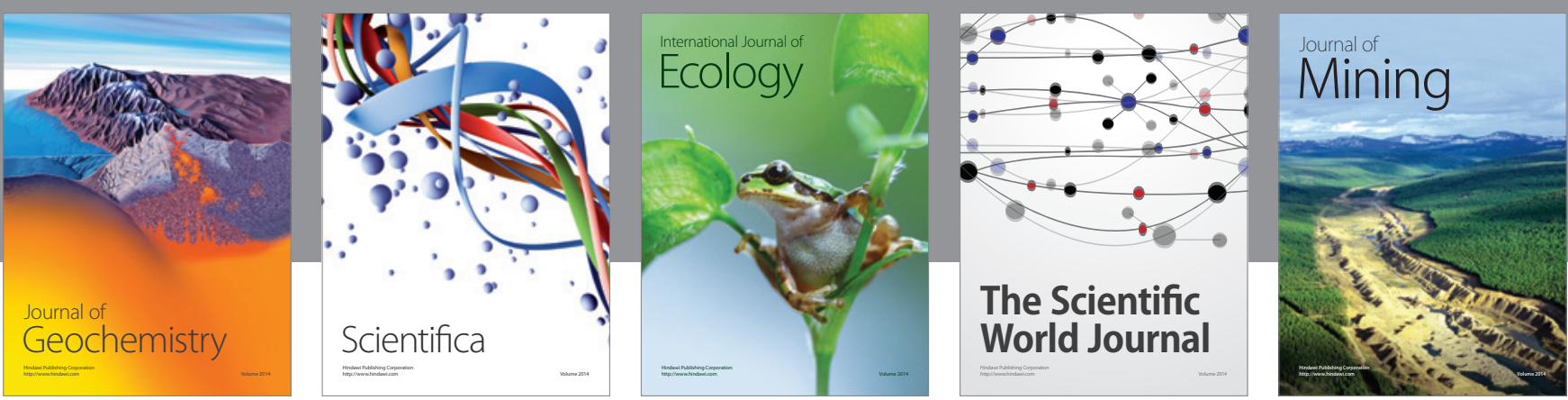

The Scientific World Journal
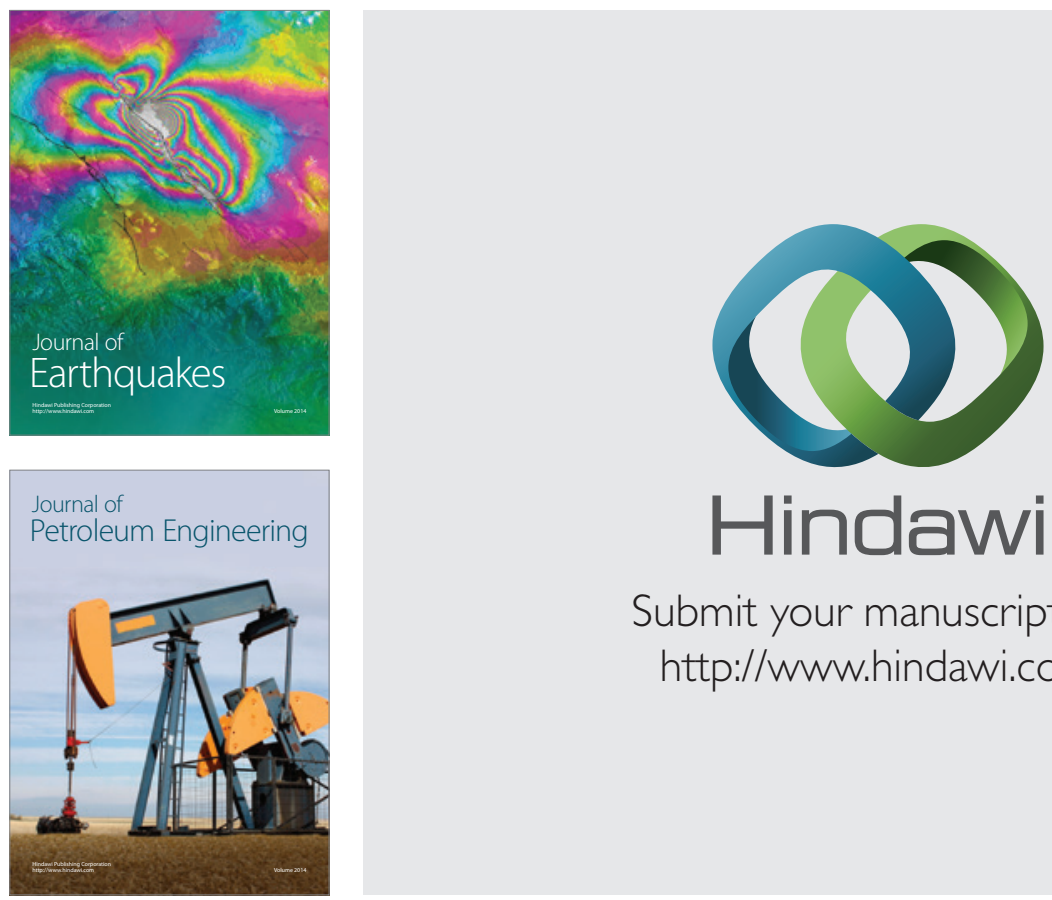

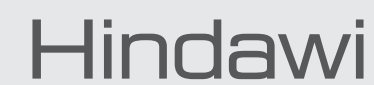

Submit your manuscripts at

http://www.hindawi.com
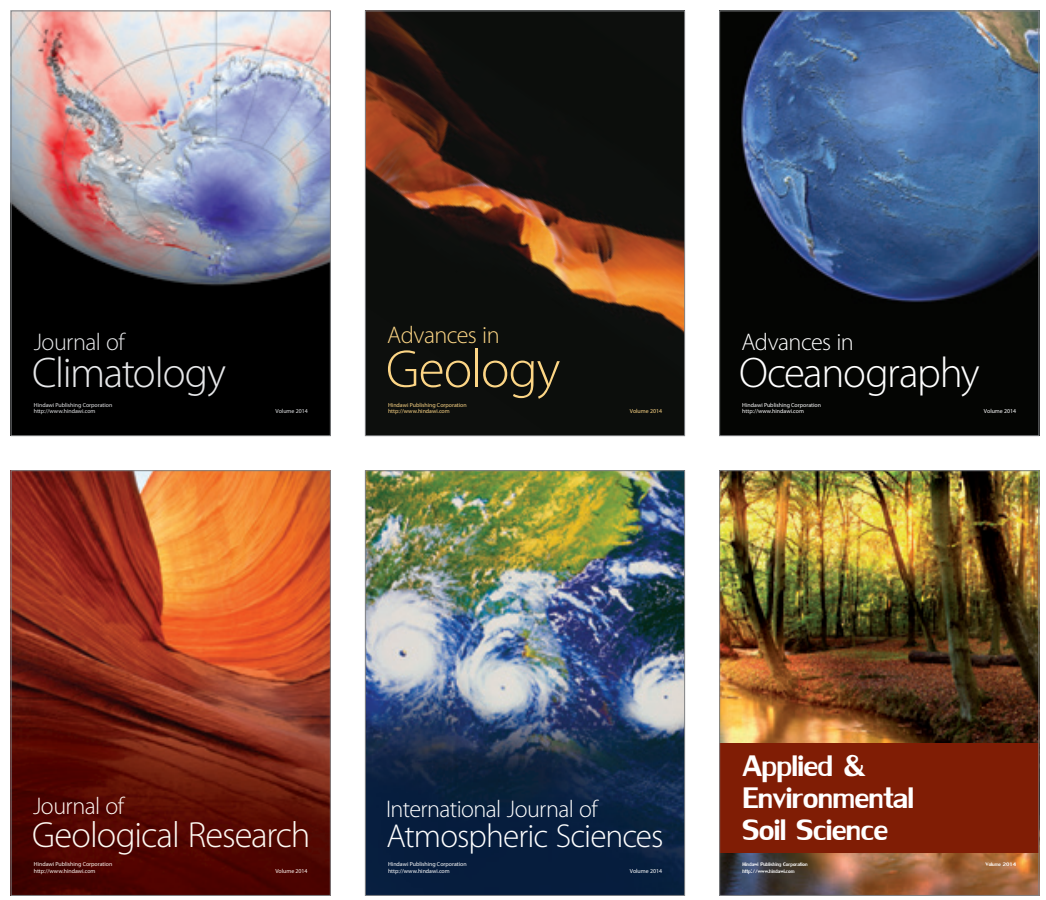
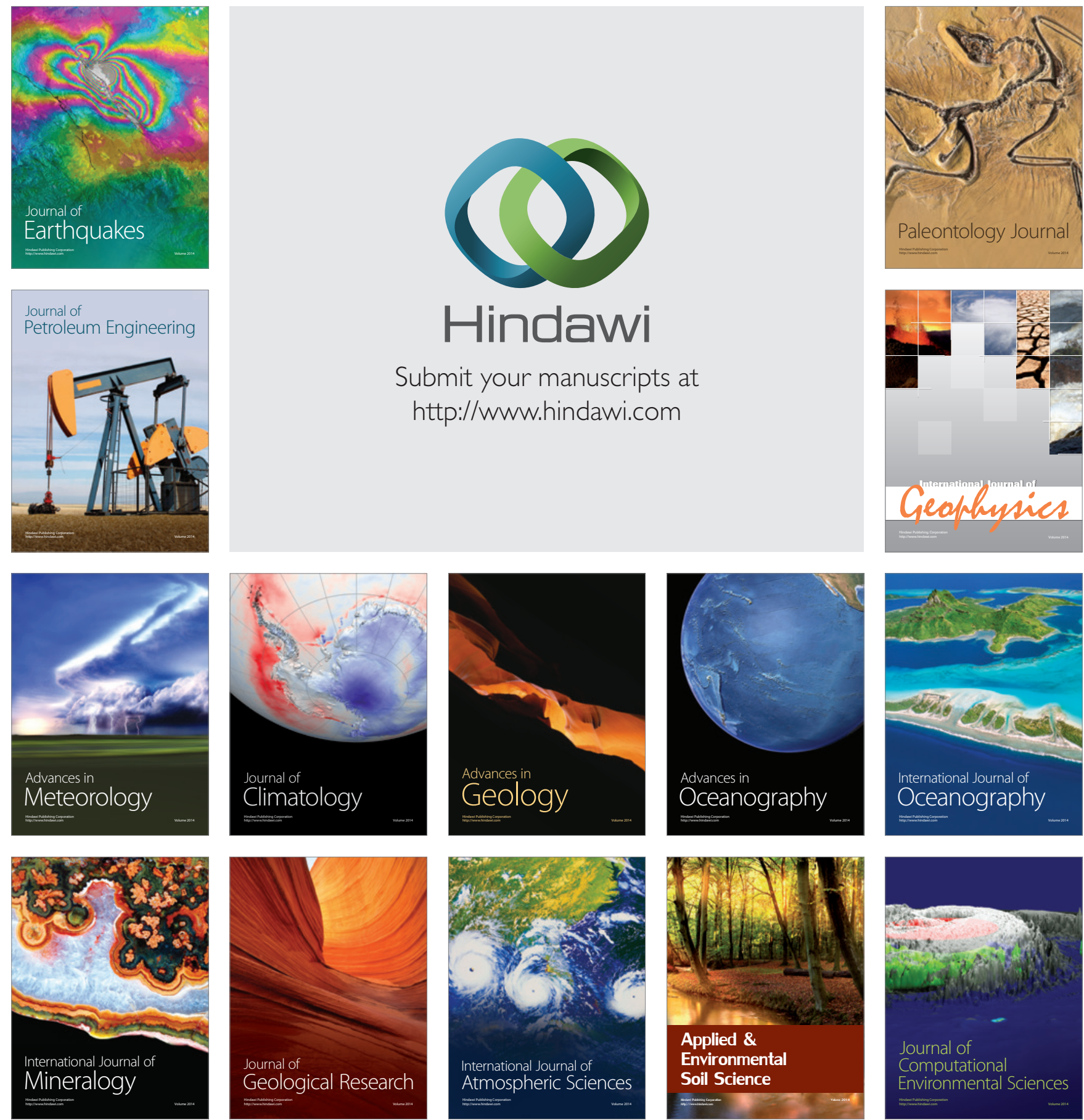